\title{
Stress Analysis on Tubesheet Referring to TEMA Standard
}

Krisdiyanto ${ }^{a}$, Muhamad Naufal Fikrib, Rahmad Kuncoro Adic, Ahmad Restian Adi Nugrohod

a,b,d Department of Mechanical Engineering, Faculty of Engineering, Universitas Muhammadiyah Yogyakarta,

Jl. Brawijaya, Geblagan, Tamantirto, Kec. Kasihan, Bantul, Yogyakarta

e-mail: krisdiyanto@umy.ac.id, muhamad.naufal.2016@ft.umy.ac.id, ahmad.restian.2016@ft.umy.ac.id

c Department of Mechanical and Industrial Engineering, Faculty of Engineering, Universitas Gadjah Mada,

J1. Grafika No. 2, Yogyakarta 55281, Indonesia

e-mail: rahmad.kuncoro.adi@mail.ugm.ac.id

\begin{abstract}
ABSTRAK
Kata kunci:

Finite element

Tegangan

Overdesign

Tubesheet

Alat penukar kalor merupakan sebuah peralatan yang digunakan untuk memindahkan kalor tanpa disertai dengan perpindahan massa. Peralatan tersebut harus didesain berdasarkan standar yang telah ditetapkan. Standar yang banyak digunakan yaitu standar yang dikeluarkan oleh TEMA (Tubular Exchanger Manufacturer Association). Hasil desain alat penukar kalor dengan standar tersebut dirasa kurang efisien dilihat dari sisi materialnya. Efisiensi material yang digunakan dapat dianalisis dengan analisis tegangan pada komponen yang menahan gaya dan salah satu komponen tersebut yaitu tubesheet. Analisis tegangan pada tubesheet dapat menggunakan software berbasis finite element. Hasil analisis menunjukkan bahwa desain tubesheet pada desain yang mengacu pada standar TEMA relative aman karena tegangan von Mises maksimal berada dibawah yield strength material yang digunakan, sedangkan nilai overdesign relative besar karena tegangan von Mises rata-rata juga berada jauh dibawah yield strength material yang digunakan.
\end{abstract}

Keyword:

Finite element

Stress

Overdesign

Tubesheet

\section{ABSTRACT}

A heat exchanger is a device used to transfer heat without mass transfer. The equipment must be designed according to established standards. The standard that is widely used is the standard issued by TEMA (Tubular Exchanger Manufacturer Association). The results of the design of the heat exchanger with these standards are considered less efficient in terms of the material. The efficiency of the material used can be analyzed by stress analysis on the components that withstand the force, and one of these components is the tube sheet. Stress analysis on tube sheets can use finite element-based software. The results of the research show that the tube sheet design that refers to the TEMA standard is relatively safe because the maximum von Mises stress is below the yield strength of the material used, while the overdesign value is rather significant because the average von Mises stress is also far below the yield strength of the material used.

\section{INTRODUCTION}

The heat exchanger is the main equipment in the industry to transfer heat without mass [1], [2]. Conduction and convection processes occur in the device [3]. The most widely used heat exchanger is shell and tube heat exchanger because it has a simple construction, easy maintenance process, and can be used in various conditions [4]-[6]. The shell and tube heat exchanger design usually refers to a standard [7], and the standard that is widely used is the standard from the Tubular Exchanger Manufacturer Association or TEMA [8], but many opinions state that this standard results in an inefficient design [9]. Dimensions in the design affect the stress [10], and the average stress analysis can be used to analyze the efficiency of the material used [11], while the maximum stress analysis can be used to obtain the safety value [12] [13]. Stress on equipment can occur because there is a force acting on the equipment [12]. The stress that occurs in equipment or component can be analyzed by the finite element method (FEM) [14]. 
One of the components in the heat exchanger is tube sheet and tube sheet design refer to the TEMA standard. Therefore, the stress analysis on the tube sheet needs to be investigated to know the distribution stress on the component, the safety, and the overdesign of the tube sheet.

\section{METHODS}

The first step in this research is to study the literature and obtain the daily production capacity of the heat exchanger. The production capacity is used to determine the overall dimensions of the heat exchanger. The specifications of the heat exchanger are calculated based on the standards issued by TEMA. After obtaining the specifications of the heat exchanger as shown in Table 1, the next process is to design the geometry of the heat exchanger using Autodesk Inventor Software.

Table 1 Shell and Tube Heat Exchanger Specifications

\begin{tabular}{ccc}
\hline No & Specification & Value \\
\hline 1 & Type & BEM (horizontal) \\
2 & Standard & TEMA \\
3 & Material & SS 304 \\
4 & Safety Factor & 2 \\
5 & Yield Strength & $205 \mathrm{MPa}$ \\
6 & Allowable Stress & $102,5 \mathrm{MPa}$ \\
7 & Shell Diameter & $273,1 \mathrm{~mm}$ \\
8 & Shell Thickness & $3,4 \mathrm{~mm}$ \\
9 & Tubesheet Diameter & $266,3 \mathrm{~mm}$ \\
10 & Tubesheet Thickness & $19,1 \mathrm{~mm}$ \\
11 & Baffle Type & Segmental \\
12 & Baffle Cut & $25 \%$ \\
13 & Number of Baffles & 2 \\
14 & Number of Tie Rod & 4 \\
15 & Tie Rod Diameter & $9,5 \mathrm{~mm}$ \\
16 & Tube Diameter & $19,05 \mathrm{~mm}$ \\
17 & Tube Thickness & $0,5 \mathrm{~mm}$ \\
18 & Number of Tube & 64 \\
19 & Internal Pressure (shell) & $0,36 \mathrm{MPa}$ \\
\hline
\end{tabular}

The results of the geometry design of the heat exchanger using Autodesk Inventor software are shown in Figure 1. The geometry is then imported into the SimScale platform for stress analysis to determine the stress distribution that occurs in the equipment.
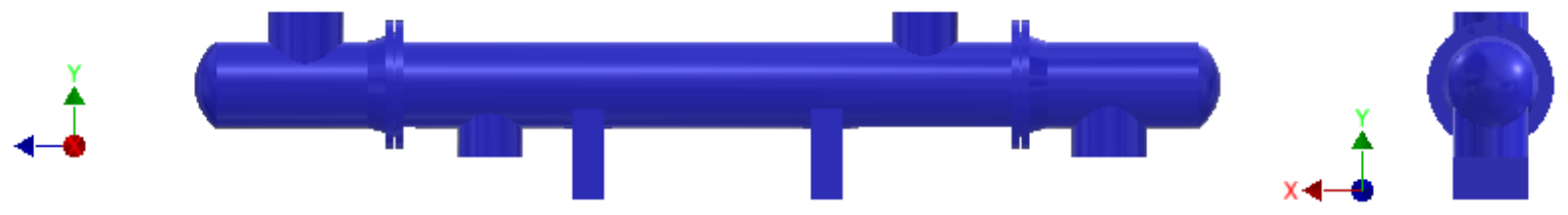

Figure 1 Shell and tube heat exchanger geometry

Von mises stress on the simulation results' shell compared with the calculated stress using equation 1 [15]. These calculations are used to validate that the simulation results are accurate [16]. The allowable deviation rate is $5 \%$ [17].

$$
\sigma_{v m}=\sqrt{\sigma_{1}^{2}-\sigma_{3} \cdot \sigma_{1}+\sigma_{1}^{2}}
$$

where:

$\sigma_{1} \quad$ : hoop stress (MPa) 


$$
\begin{array}{ll}
\sigma_{3} & : \text { longitudinal stress (MPa) } \\
\sigma_{v m} & : \text { von Mises stress (MPa) }
\end{array}
$$

Equation 1 requires longitudinal stress and hoop stress values. Longitudinal stress can be calculated by equation 2 , and hoop stress can be calculated by equation 3 [18].

$$
\begin{gathered}
\sigma_{L}=\frac{P D}{4 t} \\
\sigma_{H}=\frac{P D}{2 t}
\end{gathered}
$$

where:

$\begin{array}{ll}P & : \text { internal pressure (MPa) } \\ D & : \text { shell diameter (m) } \\ t & \text { : shell thickness (m) }\end{array}$

The accurate simulation results are then used to conclude the design safety and material efficiency by calculating the tube sheet overdesign value. The overdesign value can be calculated by equation 4 [19].

$$
\% \text { Overdesign }=\frac{\left|\sigma_{\text {allowable }}-\sigma_{\text {average }}\right|}{\sigma_{\text {average }}}
$$

where:

$$
\begin{array}{ll}
\sigma_{\text {allowable }} & : \text { allowable stress }(\mathrm{MPa}) \\
\sigma_{\text {average }} & : \text { average stress }(\mathrm{MPa})
\end{array}
$$

\section{RESULT AND DISCUSSION}

The simulation results of applying pressure to the geometry using the SimScale platform is von Mises stress distribution on the shell are shown in Figure 2, tube sheet 1 in Figure 3, and tube sheet 2 in Figure 4. The stress on the shell presented in Figure 2 is used to validate the simulation results. Tubesheets 1 and 2 presented in Figures 3 and 4 are used to conclude the safety and efficiency of the component design.

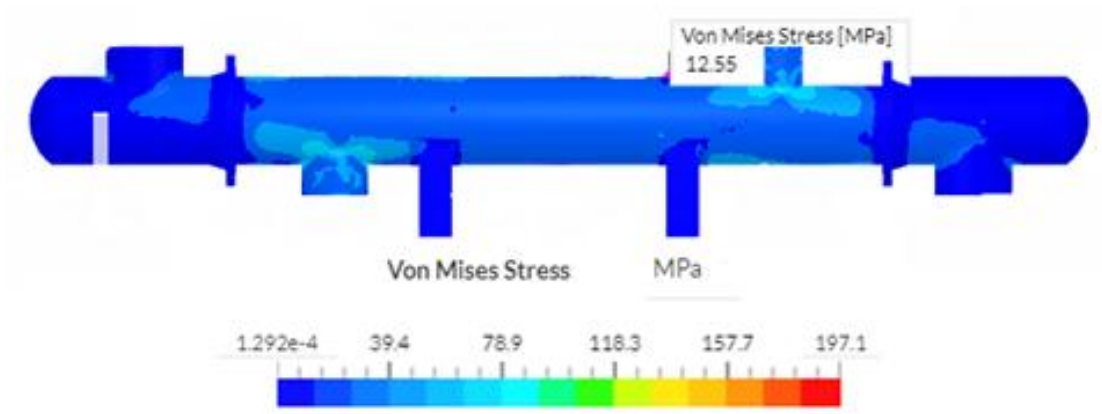

Figure 2 Stress distribution on the shell

Validation is done by comparing the von Mises stress on the shell presented in Figure 2 and the calculation results using equation 1 . The stress calculation results using equation 1 are $12.20 \mathrm{MPa}$, and the simulation stress is $12.55 \mathrm{MPa}$. The deviation of the simulation results is $2.8 \%$. These results are still below the predetermined limit of $5 \%$ and are considered valid simulation results. 


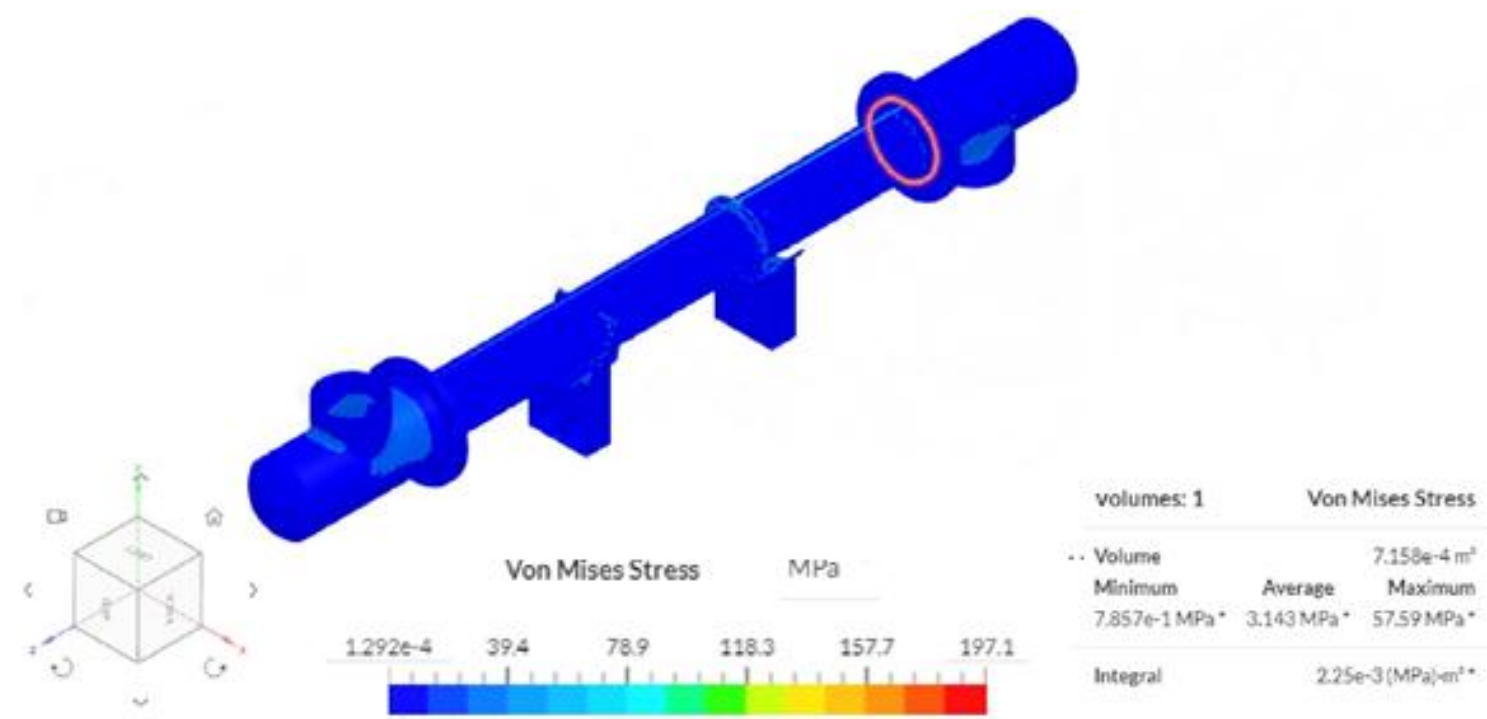

Figure 3 Stress distribution on tube sheet 1

The maximum stress on tube sheet 1 is $57.59 \mathrm{MPa}$. Therefore, it is still relatively far below the yield strength of the material used in the equipment so that it can be ascertained that the design of tube sheet 1 , which refers to the TEMA Standard, is still safe from failure. While the average stress on these components is 3,143 MPa, it can be ascertained that tube sheet 1 has an overdesign value of $3164 \%$ or is very wasteful of material because it has dimensions that exceed the design requirements.

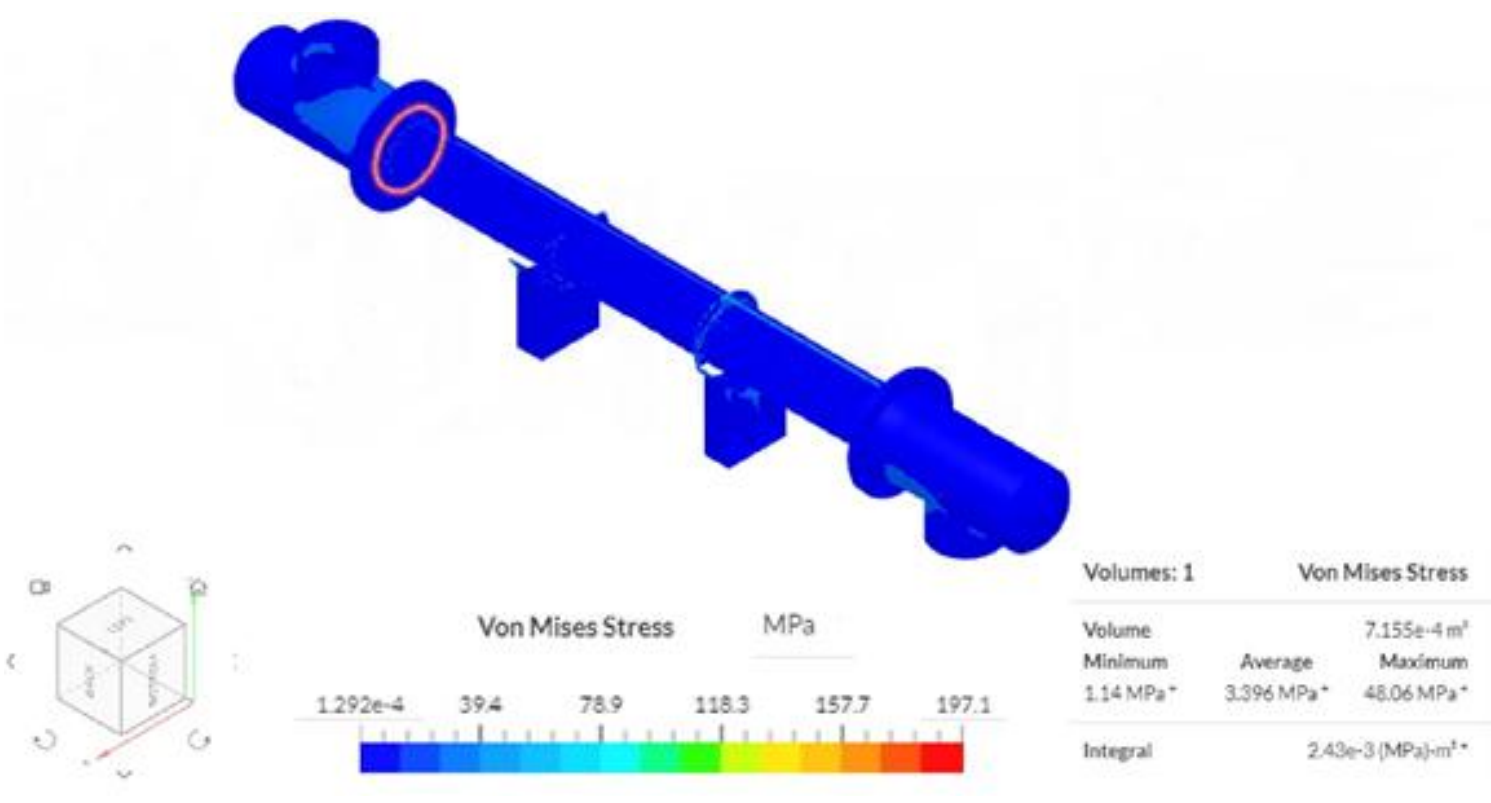

Figure 4 Stress distribution on tube sheet 2

The maximum stress on tube sheet 2 is $48.06 \mathrm{MPa}$. The maximum stress is still relatively far below the yield strength of the material used in the equipment so that it can be ascertained that the design of tube sheet 2, which refers to TEMA Standard, is still safe from failure. On the other hand, the average stress on these components is $3.396 \mathrm{MPa}$, so that it can be ascertained that tube sheet 2 has an overdesign value of $2923 \%$ or is very wasteful of material because it has dimensions that exceed the design requirements. However, in determining the tube sheet specifications, the maximum and average stress values must be considered. 


\section{CONCLUSION}

The simulation results show that the tube sheet design following the TEMA standard has very high safety. The maximum von mises stress is very far below the yield strength value of the material used; besides that, there is material wastage or overdesign because the stress on the tube sheet is very high. After all, it is below the yield strength of the material used.

\section{REFERENCES}

[1] Sekulic DP. A reconsideration of the definition of a heat exchanger. Int J Heat Mass Transf. 1990;33(12):2748-50.

[2] Bagi JS, Mane VN, Datye AB. Improvement in Quality Dimensions of Shell and Tube Type Heat Exchanger by Using Design. 2014;(September).

[3] Thirumarimurugan M, Kannadasan T, Ramasamy E. Performance analysis of shell and tube heat exchanger using the miscible system. Am J Appl Sci. 2008;5(5):548-52.

[4] Costa ALH, Queiroz EM. Design optimization of shell-and-tube heat exchangers. Appl Therm Eng. 2008;28(14-15):1798-805.

[5] Fesanghary M, Damangir E, Soleimani I. Design optimization of shell and tube heat exchangers using global sensitivity analysis and harmony search algorithm. Appl Therm. Eng. 2009;29(56):1026-31. Available from: http://dx.doi.org/10.1016/j.applthermaleng.2008.05.018

[6] Hadidi A, Hadidi M, Nazari A. A new design approach for shell-and-tube heat exchangers using an imperialist competitive algorithm (ICA) from economic point of view. Energy Convers Manag. 2013;67:66-74. Available from: http://dx.doi.org/10.1016/j.enconman.2012.11.017

[7] Shirode KD, Rane DS, Naik MY. Comparison of Design and Analysis of Tubesheet Thickness by Using UHX Code of ASME and TEMA Standard. 2013;96-108.

[8] Ozden E, Tari I. Shell side CFD analysis of a small shell-and-tube heat exchanger. Energy Convers Manag. 2010;51(5):1004-14.

[9] Mizutani FT, Pessoa FLP, Queiroz EM, Hauan S, Grossmann IE. Mathematical programming model for heat-exchanger network synthesis including detailed heat-exchanger designs. 2. Network synthesis. Ind Eng Chem Res. 2003;42(17):4019-27.

[10] Xu S, Wang W. Numerical investigation on weld residual stresses in tube to tube sheet joint of a heat exchanger. Int J Press Vessel Pip. 2013;101:37-44. Available from: http://dx.doi.org/10.1016/j.ijpvp.2012.10.004

[11] Liang Q. Performance-Based Optimization of Structures: Theory and Applications. Engineering Optimization. London: Spon Press; 2007. Available from: http://doi.wiley.com/10.1002/0470867353\%5Cnhttp://www.tandfonline.com/doi/abs/10.1080/0305215 0008941321

[12] James R. Farr MHJ. Guidebook for the Design of ASME Section VIII Pressure Vessel. Angewandte Chemie International Edition, 6(11), 951-952. New York: ASME Press; 2001.

[13] Li F, Xing J, Liu Y. Thermal analysis and stress analysis of the heat-exchange pipe based on ANSYS. In: Proceedings - 4th International Conference on Information and Computing, ICIC 2011. Phuket, Thailand; 2011. p. 283-5.

[14] Yang L, Weinberger C, Shah YT. Finite element analysis on horizontal vessels with saddle supports. Comput Struct. 1994;52(3):387-95.

[15] Claud Way. Plasticity in Physics. New York: The English Press; 2016.

[16] Oberkampf WL, Trucano TG, Hirsch C. Verification, validation, and predictive capability in computational engineering and physics. Appl Mech Rev. 2004;57(5):345-84.

[17] Franck H, Franck D. Forensic engineering fundamentals. Forensic Engineering Fundamentals. 2012. $1-454 \mathrm{p}$.

[18] Khurmi, R., Gupta J. A Textbook of Machine Design. Vol. I, System. Eurasia Publishing House (PVT.) LTD.; 2005.

[19] Beyers WA, Zapke A, Venter G. Improved Cover Type Header Box Design Procedure. R\&D J. 2015;31(December):76-85. 